\title{
Effect of Four Different Salts on Seed Germination and Morphological Characteristics of Oryza sativa L. cv. MR219
}

\author{
Nahid Kalhori ${ }^{1}$, Tung Ying ${ }^{1}$, Rosimah Nulit ${ }^{1 *}$, Mahbod Sahebi ${ }^{2}$, Rambod Abiri ${ }^{3}$, \\ Narges Atabaki ${ }^{3}{ }^{4}$ \\ ${ }^{I}$ Department of Biology, Faculty of Science, Universiti Putra Malaysia, 43400 UPM Serdang, Selangor, \\ Malaysia. \\ ${ }^{2}$ Institute of Tropical Agriculture, Universiti Putra Malaysia, 43400 UPM Serdang, Selangor, Malaysia. \\ ${ }^{3}$ Department of Biochemistry, Faculty of Biotechnology and Molecular Science, Universiti Putra Malaysia, \\ 43400 UPM Serdang, Selangor Malaysia.
}

${ }^{4}$ Islamic Azad University, Science and Research Branch, 1477893855, Tehran, Iran.

*Corresponding Author: Rosimah Nulit, Department of Biology, Faculty of Science, Universiti Putra Malaysia, 43400 UPM Serdang, Selangor, Malaysia.

\begin{abstract}
The response of Oryza sativa L. cv. MR219 to $\mathrm{NaCl}, \mathrm{KCl}, \mathrm{MgCl}_{2}$ and $\mathrm{MgSO}_{4}$ at different salinity levels $(0,50,100,150,200$ and $250 \mathrm{mM})$ was studied with emphasis on seed germination and early seedling stage. High salinity delayed mean germination time of seeds and increased biomass, relative injury rate and seedling height reduction. Seeds are more tolerant to $\mathrm{NaCl}$ among four salts even at the highest salinity. Results showed that $50 \mathrm{mM} \mathrm{KCl}$ enhanced the root growth with more roots developed at this salinity. Abnormal seed germination was found in $\mathrm{MgCl}_{2}$ and $\mathrm{MgSO}_{4}$ due to inhibition of root growth. This study proposes that degree of tolerance of MR219 to salts from morphological results is $\mathrm{NaCl}>\mathrm{KCl}>\mathrm{MgCl}_{2}>\mathrm{MgSO}_{4}$. This study might be useful for further research of salinity effect on growth and physiological processes at advanced stage of MR 219 growth.
\end{abstract}

Keywords: Seedling, salinity, $\mathrm{NaCl}, \mathrm{KCl}, \mathrm{MgCl}_{2}, \mathrm{MgSO}_{4}$

\section{INTRODUCTION}

Plants are usually exposed to abiotic stress, such as drought, temperature, salinity, metal toxicity, herbicides in which all these could potentially affect the crop production (Hasanuzzaman et al., 2013). Among all abiotic stresses, salinity is one of the most brutal environmental constraints that bring detrimental effects on productivity and crop loss worldwide (Teh et al., 2014). Under high salt stress conditions, most of the crop plants are susceptible and unable to survive. Increased salinization in coastal areas and arable land is predicted to become a huge problem throughout much of the world. Approximately $6.5 \%$ of world's total area and about $20 \%$ of the cultivated area is already affected by soil salinity. All over the world, about 397 million ha of land has been affected by different type of salts such as sodium chloride $(\mathrm{NaCl})$, calcium chloride $\left(\mathrm{CaCl}_{2}\right)$, sodium sulphate $\left(\mathrm{Na}_{2} \mathrm{SO}_{4}\right)$, and magnesium sulfate $\left(\mathrm{MgSO}_{4}\right)$ (Hakim et al., 2014).

Crop plants exhibit a spectrum of reactions against salinity. Salt stress has two primary harmful effects; osmotic and ionic stress. Osmotic stress leads to reduction of water uptake by root, and accumulation and toxicity of specific ions caused ionic stress. Both ionic and osmotic stresses lead to reduced growth rates and eventually to plant death. Followed by primary stresses, oxidative damage as secondary stress may occur (Gupta \& Huang, 2014). Besides, the impact of salinity on plant growth and development can be related to alteration in morphology, anatomy and metabolism(Molassiotis et al., 2006; Amirjani, 2010), but adjustment of these parameters greatly depend on the degree of damage, duration of stress exposure and plant species (Amirjani, 2010).

Seed is the basic key to connect two generations of plant life. Actually, seed acts as the intermediate for the genetic transfer between generations and therefore the roles of a seed to ensure the continuity 
of plant survival are obviously vital for successful crop production(He \& Yang, 2013). Seed germination is a complex physiological and biochemical process that involves a series of signal transduction and gene expression regulation. Different crops show their particular germination patterns under saline environment or even more varied response can be observed among different varieties of the same crop(Hakim et al., 2010; J. Singh et al., 2012; Jaarsma et al., 2013; Panuccio et al., 2014). Plants at germination stage are more sensitive to environmental stress compared to other growth and development phases (Luan et al., 2014). Rice (Oryza sativa L.) is one of the most significant staple crops which classified within the sensitive division from 0 to $8 \mathrm{dSm}^{-1}$ based on the classification of crop tolerance to salinity (Zhu et al., 2001). A plenty of research had been done to evaluate salinity tolerance of different verities of rice (Hakim et al., 2010; Jamil et al., 2012). However, the effects of various salt types on seed germination and early seedling growth of Oryza sativa L. cv. MR219 are not fully understood and thus the study of the seed response to various salts is actually desirable.

In recent years, the need of improvement and production of salt- tolerant in crop, rice in particular, has becomes eventually significant. According to The United Nation report (2016), human population is estimated reach to 8.5 billion by 2030, 9.7 billion in 2050 and 11.2 billion in 2100 . With the ultimate goal to ensure food security for supporting the growing population, somehow great focus on understanding the response of this important crop towards environmental stress especially salinity is necessary (Amirjani, 2010). Besides, it is usually costly and time-consuming to reclaim salt-affected land (Tsegay \& Gebreslassie, 2014). Therefore, this crisis attracts many scientists to gain their interest in developing salt tolerant rice cultivars to prevent the unnecessary loss in agriculture and at the same time reduce food shortage problems (Hakim et al., 2014).Thus, it is crucial to develop high yielding, salt-tolerance rice varieties as a mean of expanding agriculture into the regions affected by salinity.

\section{Materials And Methods}

\subsection{Plant Materials and Seed Sterilization}

Seeds of Oryza sativa cv. MR 219 were obtained from Malaysian Agriculture Research and Development Institute (MARDI), Kuala Selangor, Selangor. Seed sterilization was done according to report by (Htwe et al., 2011) with slight modification. Healthy, vigorous and uniform size seeds were selected and surface sterilized with $70 \%$ ethanol solution for 30 seconds. Seeds were washed in 5\% sodium hypochlorite solution containing one drop of Tween 20 for another 20 minutes. Seeds were washed thoroughly with autoclaved distilled water for 5 times and followed by air dried with tissue paper.

\subsection{Experimental design and Salinity Treatments}

The types of salt used were $\mathrm{NaCl}$ (Sigma, USA), $\mathrm{KCl}$ (Univar, Australia), $\mathrm{MgCl}_{2}$ (Merch, Germany) and $\mathrm{MgSO}_{4}$ (Bio Basic, Canada).In order to compare the effect of different salts on seed germination, seven sterilized seeds were spread and allowed to grow on Whatman No.1 filter paper in a 9-cm-diam sterilized Petri dish which is shown in Figure 3.1. Each filter paper was moistened with salt solutions of 0 (deionized water) as a control, 50,100,150, 200 and $250 \mathrm{mM}$ salt concentrations according to different salt types (Khan et al., 1997). $5 \mathrm{ml}$ of respective concentrations for each salt type was introduced to each Petri dish. The treatments were placed in growth chamber with the room temperature was set within $25 \pm 1{ }^{\circ} \mathrm{C}$ with $12 \mathrm{~h}$ daylight for two weeks (Hakim et al., 2010). All petri dishes were arranged in a completely randomized design (CRD) with two replications for each treatment (Carpýcý et al., 2009). The experiment was repeated thrice to ensure the consistency of result.

\subsection{Observation and Data Collection}

Daily observation and counting of the number of seeds which were sprouted and germinated were done up to fourteen days. Sprouted seeds were referred to the seeds which have reached the ability to produce at least one noticeable plumule or radicle (M. S. Rahman et al., 2001). Seeds were considered germinated with at least $2 \mathrm{~mm}$ radicle emergence from the seed coat. After fourteen days of treatment application, measurement of parameters were done and calculated. The parameters studied in the experiment including water uptake percentage, germination percentage, germination index, relative injury rate, seed vigor, mean germination time, biomass and salt tolerance (Tsegay \& Gebreslassie, 
2014). For each treatment of every salt type, three seedlings were randomly selected for measurement of morphological characteristics, including seedling height, length of shoot, length of root and length of leaf (Zhang et al., 2014). Morphological characteristics of leaf and root for every treatment at early seedling stage was observed using dissecting microscope and recorded.

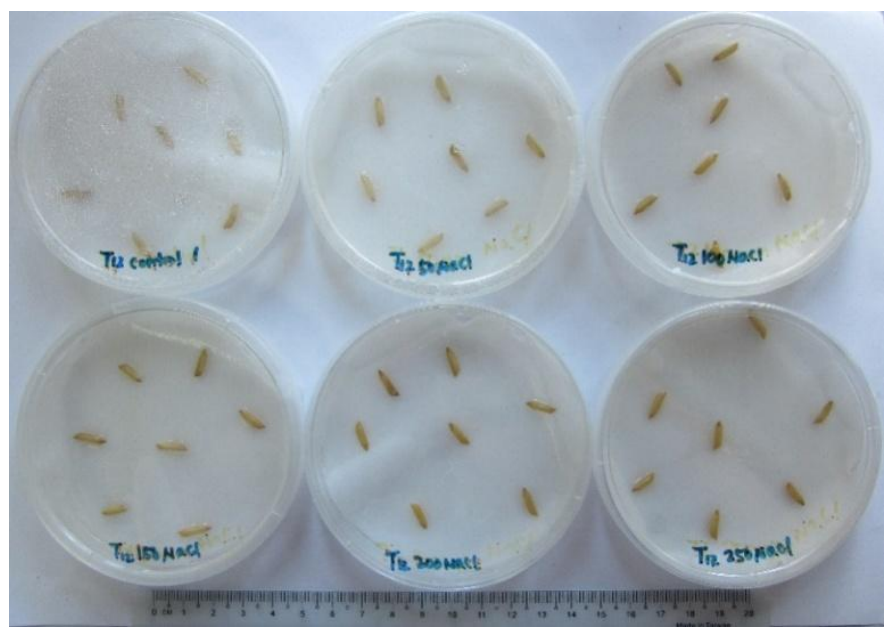

Figure 1. Seven seeds were germinated in petri dish for all treatments

\subsection{Measurement of Water Uptake Percentage}

Dry weight of selected seeds was weighed before seed surface sterilization process was carried out. Seven seeds were placed in each Whatman No.1 filter paper. $10 \mathrm{ml}$ of appropriate salt concentrations for each salt type $\left(\mathrm{NaCl}, \mathrm{KCl}, \mathrm{MgCl}_{2}\right.$ and $\left.\mathrm{MgSO}_{4}\right)$ were added to each petri dish. The seeds were watered with different salt solutions and left for $24 \mathrm{~h}$. Fresh weight of seeds in each treatment was recorded in order to determine the water uptake by seeds (Gairola et al., 2011).

$$
\text { water uptake percentage }=\frac{\text { seed fresh weight-seed dry weight }}{\text { seed fresh weight }} \times 100
$$

\subsection{Measurement of Germination Percentage (GP)}

Germination percentage refers to the actual percentage of total number of seeds in the sample that are germinated in an experiment which plays vital role in the comparison of seed collections quality in research (FAO, 1983). This parameter was calculated according to (Kandil et al., 2012).

$$
\mathrm{GP}=\frac{\text { Number of germinated seeds }}{\text { Total number of seeds sown }} \times 100
$$

\subsection{Measurement of Germination Index (GI)}

Germination index can be referred as the sum of germinated seeds in certain day divided by the number of germination days corresponding. The formula proposed by $(\mathrm{Li}, 2008)$ was used for the determination of germination index for each treatment.

$$
\mathrm{GI}=\sum \frac{\mathrm{Gt}}{\mathrm{Dt}}
$$

Where Gt is germinated seeds in $\mathrm{t}$ days and $\mathrm{Dt}$ is the number of germination days corresponding.

\subsection{Measurement of Relative Injury Rate (RIR)}

Calculation of relative injury rate for each salt type with respective salinity levels was done by finding the difference between germination percentage in control and germination percentage in salt treated seeds and then following by division of germination percentage in control $(\mathrm{Li}, 2008)$. 


$$
\mathrm{RIR}=\frac{\text { GP in control-GP in salt treated seeds }}{\text { GP in control }}
$$

\subsection{Measurement of Mean Germination Time (MGT)}

Mean germination time refers to the average time a seed needs for initiation and ending of germination process. MGT value for each salt treatment was counted by the method reported by (Ellis \& Roberts, 1981).

$$
\operatorname{MGT}=\frac{\sum \mathrm{Dn}}{\sum \mathrm{n}}
$$

Where $\mathrm{n}$ is the number of germinated seeds which are germinated on day " $\mathrm{D}$ ", and " $\mathrm{D}$ " is the number of days counted from beginning of germination.

\subsection{Measurement of Seed vigor}

Seed vigor can be defined as the total seed properties that function as the indicator for activity level and performance of seed during germination and seedling emergence. Besides, it also reflects the reduction of seed in ability to carry out all physiological activities that enable them to perform. Value of seed vigor was determined by method proposed by (Abdul-Baki \& Anderson, 1973).

$$
\text { Seed vigor }=\frac{(\text { Length of hypocotyl+length of radical) }}{100} \times \text { GP }
$$

\subsection{Measurement of Biomass}

Fresh weight and dry weight of seedling before and after salt treatments are necessary for determination of biomass. Fresh weight of seedlings in each treatment was obtained on the day of harvest (Day 14). Next, fresh seedling samples were dried at $78^{\circ} \mathrm{C}$ for $48 \mathrm{~h}$ for weight standardization. Seedlings were then weighed again to obtain the dry weight (Carpýcý et al., 2009).

\subsection{Measurement of Salt Tolerance (ST)}

Salt tolerance can be calculated by referring to (Tsegay \& Gebreslassie, 2014).

$$
\text { ST }=\frac{\text { Seedling dry weight of salt treatment }}{\text { Seedling dry weight in control }} \times 100
$$

\subsection{Measurement of Seedling Height Reduction (SHR)}

Seedling height reduction that illustrates the growth suspension in root length and shoots length represented in percentage was calculated by following equation (Islam \& Karim, 2010).

$$
\mathrm{SHR}=\frac{\text { Seedling height at control-Seedling height at saline condition }}{\text { Seedling height at control }}
$$

\subsection{Statistical analysis}

All data were analysed using SPSS Statistic window version 21. Two-way Analysis of Variance (ANOVA) at confidence level $P \leq 0.05$ was performed to determine the significance of difference among salt treatments and concentrations followed by Tukey multiple for mean comparison test.

\section{RESUlT}

\subsection{Water uptake percentage}

Table 1 shows that the water uptake percentage of MR219 seeds under all salt treatments were inversely related to salt concentration level. The water uptake percentage reduced significantly $(P \leq 0.05)$ in $\mathrm{KCl}$ and $\mathrm{MgCl}_{2}$ but not significantly reduced in $\mathrm{NaCl}$ and $\mathrm{MgSO}_{4}$ with increased salt levels. However, most treatments showed no significant difference comparing with control. 
Effect of Four Different Salts on Seed Germination and Morphological Characteristics of Oryza sativa L. cV. MR219

Table 1. Mean comparison for effect of $\mathrm{NaCl}, \mathrm{KCl}, \mathrm{MgCl}_{2}$ and $\mathrm{MgSO}_{4}$ on the water uptake percentage of Oryza sativa L. cv. MR219 seeds

\begin{tabular}{|l|l|l|l|l|}
\hline \multicolumn{5}{|c|}{ Water uptake percentage $(\%)$} \\
\hline Concentration(mM) & $\mathbf{N a C l}$ & KCl & $\mathbf{M g C l}_{\mathbf{2}}$ & $\mathbf{M g S O}_{\mathbf{4}}$ \\
\hline $0($ control$)$ & $21.7^{\mathrm{a}} \pm 2.8$ & $21.7^{\mathrm{a}} \pm 2.8$ & $21.7^{\mathrm{a}} \pm 2.8$ & $21.7^{\mathrm{a}} \pm 2.8$ \\
\hline 50 & $19.1^{\mathrm{ab}} \pm 2.4$ & $18.8^{\mathrm{ab}} \pm 1.61$ & $19.2^{\mathrm{ab}} \pm 2.11$ & $20.5^{\mathrm{ab}} \pm 0.86$ \\
\hline 100 & $18.4^{\mathrm{ab}} \pm 1.8$ & $18.1^{\mathrm{ab}} \pm 2.84$ & $18.3^{\mathrm{ab}} \pm 1.86$ & $19.1^{\mathrm{ab}} \pm 1.16$ \\
\hline 150 & $18.3^{\mathrm{ab}} \pm 2.6$ & $17.5^{\mathrm{ab}} \pm 1.53$ & $17.5^{\mathrm{ab}} \pm 1.84$ & $19.0^{\mathrm{ab}} \pm 2.80$ \\
\hline 200 & $18.0^{\mathrm{ab}} \pm 3.3$ & $17.3^{\mathrm{b}} \pm 1.56$ & $17.3^{\mathrm{b}} \pm 2.10$ & $17.3^{\mathrm{b}} \pm 2.97$ \\
\hline 250 & $17.9^{\mathrm{ab}} \pm 3.0$ & $17.2^{\mathrm{b}} \pm 1.38$ & $17.2^{\mathrm{b}} \pm 1.39$ & $18.9^{\mathrm{ab}} \pm 1.69$ \\
\hline
\end{tabular}

Values are mean \pm standard deviation $(n=7)$. Means within a column that have different superscript letters $(\mathrm{a}-\mathrm{b})$ are significant different from each other (Tukey HSD test, $(P \leq 0.05)$

\subsection{Germination percentage}

The results in Table 2 showed that germination percentages decreased significantly due to the increased salt concentrations. It was observed that there is no significant difference $(P \geq 0.05)$ comparing with control at $50 \mathrm{mM}$ and $100 \mathrm{mM}$ for all salts. High salinity $(250 \mathrm{mM})$ of $\mathrm{KCl}$ and $\mathrm{MgCl}_{2}$ decreased drastically the germination of the rice seeds.

Table 2. Mean comparison for effect of $\mathrm{NaCl}, \mathrm{KCl}, \mathrm{MgCl}_{2}$ and $\mathrm{MgSO}_{4}$ on germination percentage of Oryza sativa L. cv. MR219 seeds

\begin{tabular}{|l|l|l|l|l|}
\hline \multicolumn{7}{|c|}{ Germination Percentage (\%) } \\
\hline Concentration $(\mathbf{m M})$ & $\mathbf{N a C l}$ & KCl & $\mathbf{M g C l}_{\mathbf{2}}$ & $\mathbf{M g S O}_{\mathbf{4}}$ \\
\hline 0 (control) & $98.6^{\mathrm{a}} \pm 3.2$ & $98.6^{\mathrm{a}} \pm 3.2$ & $98.6^{\mathrm{a}} \pm 3.2$ & $98.6^{\mathrm{a}} \pm 3.2$ \\
\hline 50 & $92.9^{\mathrm{abc}} \pm 5.1$ & $94.9^{\mathrm{ab}} \pm 3.2$ & $92.9^{\mathrm{abc}} \pm 0.00$ & $90.0^{\mathrm{abcd}} \pm 3.9$ \\
\hline 100 & $84.3^{\mathrm{abcd}} \pm 7.8$ & $81.4^{\mathrm{abcd}} \pm 10.8$ & $92.9^{\mathrm{abc}} \pm 5.1$ & $80.0^{\mathrm{abcd}} \pm 7.8$ \\
\hline 150 & $84.3^{\mathrm{abcd}} \pm 16.3$ & $74.3^{\mathrm{bcde}} \pm 18.6$ & $84.3^{\mathrm{abcd}} \pm 11.7$ & $70.0^{\text {cdef }} \pm 7.8$ \\
\hline 200 & $68.6^{\mathrm{def}} \pm 19.3$ & $52.9^{\mathrm{efg}} \pm 13.9$ & $50.0^{\mathrm{fg}} \pm 7.1$ & $54.3^{\mathrm{efg}} \pm 8.1$ \\
\hline 250 & $50.0^{\mathrm{fg}} \pm 13.4$ & $8.6^{\mathrm{i}} \pm 5.9$ & $22.9^{\mathrm{hi}} \pm 12.8$ & $34.3^{\mathrm{gh}} \pm 5.9$ \\
\hline
\end{tabular}

Values are mean \pm standard deviation $(\mathrm{n}=5)$. Means within a column that have different superscript letters (a-i) are significant different from each other (Tukey HSD test, $P \leq 0.05$ )

The effect of different salt types on mean of germinated seeds is shown in Figure 2. It is showed that high concentrations decrease germinated seeds in all salts.High salinity delayed the seed germination of Oryza sativa L. cv. MR219 for all salts. Therefore, it was observed that the seeds required longer time to germinate and the number of germinated seeds were also reduced at higher salt concentration.

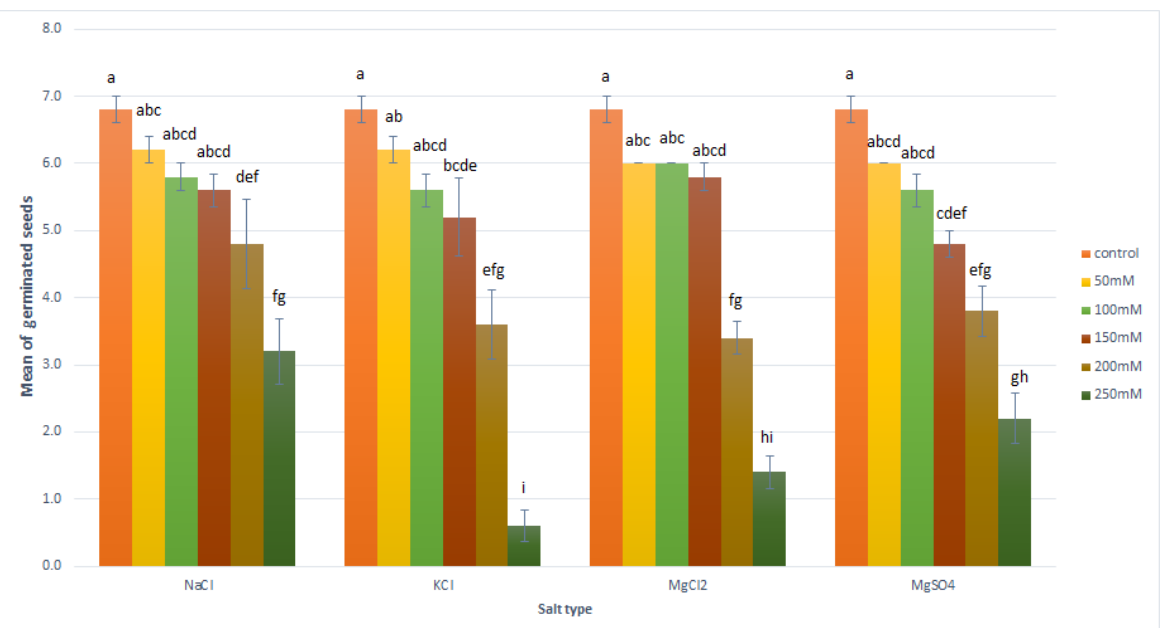

Figure 2. The mean of germinated seeds in different salinity ( $\mathrm{NaCl}, \mathrm{KCl}, \mathrm{MgCl}$ and $\left.\mathrm{MgSO}_{4}\right)$ in 14 days. Values are mean \pm standard deviation $(n=5)$. Means within a column that have different superscript letters $(a-i)$ are significant different from each other (Tukey HSD test, $P \leq 0.05$ ). 
Effect of Four Different Salts on Seed Germination and Morphological Characteristics of Oryza sativa L. cv. MR219

\subsection{Germination index}

There is no significance $(P \geq 0.05)$ difference in germination index of all salts at 50 and $100 \mathrm{mM}$ salinity levels relative to the control. Higher salt concentrations reduced significantly the germination index for all salts (Table 3). $\mathrm{MgCl}_{2}$ recorded higher germination index among four salts at $50 \mathrm{mM}$ and $100 \mathrm{mM}$ salinity levels. However, better germination index was found in $\mathrm{NaCl}$ for the remaining concentrations.

Table 3. Mean comparison for effect of $\mathrm{NaCl}, \mathrm{KCl}, \mathrm{MgCl}_{2}$ and $\mathrm{MgSO}_{4}$ on germination index of Oryza sativa $\mathrm{L}$. cv. MR219 seeds

\begin{tabular}{|l|l|l|l|l|}
\hline \multicolumn{5}{|c|}{ Germination index } \\
\hline Concentration $(\mathbf{m M})$ & $\mathbf{N a C l}$ & $\mathbf{K C l}$ & $\mathbf{M g C l}_{\mathbf{2}}$ & $\mathbf{M g S O}_{\mathbf{4}}$ \\
\hline 0 (control) & $10.9^{\mathrm{a}} \pm 0.3$ & $10.9^{\mathrm{a}} \pm 0.3$ & $10.9^{\mathrm{a}} \pm 0.3$ & $10.9^{\mathrm{a}} \pm 0.3$ \\
\hline 50 & $10.0^{\mathrm{ab}} \pm 0.4$ & $10.1^{\mathrm{ab}} \pm 0.9$ & $10.1^{\mathrm{a}} \pm 0.4$ & $9.6^{\mathrm{ab}} \pm 0.6$ \\
\hline 100 & $9.2^{\mathrm{ab}} \pm 1.0$ & $8.3^{\mathrm{abc}} \pm 1.4$ & $9.9^{\mathrm{ab}} \pm 0.8$ & $8.5^{\mathrm{abc}} \pm 0.6$ \\
\hline 150 & $8.9^{\mathrm{abc}} \pm 1.8$ & $7.4^{\mathrm{bcd}} \pm 2.1$ & $8.4^{\mathrm{abc}} \pm 1.2$ & $7.4^{\mathrm{bcd}} \pm 1.0$ \\
\hline 200 & $6.5^{\mathrm{cde}} \pm 1.5$ & $5.2^{\mathrm{def}} \pm 1.5$ & $4.7^{\mathrm{ef}} \pm 1.0$ & $5.2^{\mathrm{def}} \pm 1.1$ \\
\hline 250 & $3.7^{\mathrm{fg}} \pm 1.1$ & $0.6^{\mathrm{h}} \pm 0.5$ & $2.1^{\mathrm{gh}} \pm 1.3$ & $2.8^{\mathrm{ghb}} \pm 1.2$ \\
\hline
\end{tabular}

Values are mean \pm standard deviation $(n=5)$. Means within a column that have different superscript letters (a-h) are significant different from each other (Tukey HSD test, $P \leq 0.05$ )

\subsection{Mean germination time}

Mean germination time refers to the average time for a seed required to initiate and finish germination process. Increased salt concentrations prolonged the mean germination time in all salts which is shown in Table 4. For all salinity levels, seeds soaked in $\mathrm{NaCl}$ treatments germinated faster compared to other salts. No significant $(P \geq 0.05)$ difference in mean germination time between control and lower salinity levels $(50 \mathrm{mM}$ and $100 \mathrm{mM}$ ) for all salts except $100 \mathrm{mM} \mathrm{MgCl} 2$. On the other hand, the increased in mean germination time was more pronounced at higher salinity levels. At $50 \mathrm{mM}$ salinity, rice seeds under $\mathrm{MgSO}_{4}$ showed the longest time to germinate whereas seeds under $\mathrm{MgCl}_{2}$ at remaining salinity levels were the slowest to germinate compared to other salts.

Table 4. Mean comparison for effect of $\mathrm{NaCl}, \mathrm{KCl}, \mathrm{MgCl}_{2}$ and $\mathrm{MgSO}_{4}$ on mean germination time of Oryza sativa L. cv. MR219 seeds

\begin{tabular}{|l|l|l|l|l|}
\hline \multicolumn{5}{|c|}{ Mean Germination Time (day) } \\
\hline Concentration $(\mathbf{m M})$ & $\mathbf{N a C l}$ & KCl & $\mathbf{M g C l}_{\mathbf{2}}$ & $\mathbf{M g S O}_{\mathbf{4}}$ \\
\hline 0 (control) & $3.88^{\mathrm{a}} \pm 0.13$ & $3.88^{\mathrm{a}} \pm 0.13$ & $3.88^{\mathrm{a}} \pm 0.13$ & $3.88^{\mathrm{a}} \pm 0.13$ \\
\hline 50 & $4.04^{\mathrm{a}} \pm 0.05$ & $4.11^{\mathrm{ab}} \pm 0.10$ & $4.11^{\mathrm{ab}} \pm 0.10$ & $4.16^{\mathrm{abc}} \pm 0.09$ \\
\hline 100 & $4.36^{\mathrm{abc}} \pm 0.19$ & $4.93^{\mathrm{abcd}} \pm 0.43$ & $5.31^{\mathrm{cd}} \pm 0.49$ & $4.60^{\mathrm{abc}} \pm 0.16$ \\
\hline 150 & $4.94^{\mathrm{abcd}} \pm 0.50$ & $5.26^{\mathrm{bcd}} \pm 0.52$ & $6.88^{\mathrm{e}} \pm 0.58$ & $6.06^{\mathrm{de}} \pm 0.55$ \\
\hline 200 & $6.50^{\mathrm{e}} \pm 0.81$ & $6.88^{\mathrm{e}} \pm 0.51$ & $8.60^{\mathrm{f}} \pm 0.56$ & $8.17^{\mathrm{f}} \pm 0.53$ \\
\hline 250 & $8.80^{\mathrm{fg}} \pm 0.27$ & $10.16^{\mathrm{h}} \pm 0.57$ & $10.53^{\mathrm{h}} \pm 1.23$ & $9.80^{\mathrm{gh}} \pm 0.57$ \\
\hline
\end{tabular}

Values are mean \pm standard deviation $(n=5)$. Means within a column that have different superscript letters (a-h) are significant different from each other (Tukey HSD test, $P \leq 0.05$ )

\subsection{Biomass}

The biomass of rice seedlings for all salts after 14 days of germination showed inconsistent values with increasing salt concentrations as shown in Table 5. Basically, the biomass recorded significant increment from $0-200 \mathrm{mM} \mathrm{NaCl}$ salinity levels but declined at the highest salinity $(250 \mathrm{mM})$. For $\mathrm{KCl}$, it was observed that the biomass increased from 0-100 $\mathrm{mM}$ salinity and followed by a decline from 100-200 mM salinity. On the other hand, significant difference was shown at increasing salinity levels of $\mathrm{MgCl}_{2}$ and $\mathrm{MgSO}_{4}$ in relative to control. In $\mathrm{MgCl}_{2}$, biomass values marked increment from 0-100 mM salinity, followed by a decline at $150 \mathrm{mM}$ salinity but rose to higher value at $200 \mathrm{mM}$ salinity. No data was recorded for both $250 \mathrm{mM} \mathrm{KCl}$ and $\mathrm{MgCl}_{2}$ because growth of rice seedlings was mostly inhibited at this salinity. For $\mathrm{MgSO}_{4}$, several patterns at increasing levels were observed, for instance increment from $0-50 \mathrm{mM}$ and $100-150 \mathrm{mM}$ salinity but decline from $50-100 \mathrm{mM}$ and 150 - 
Effect of Four Different Salts on Seed Germination and Morphological Characteristics of Oryza sativa L. cV. MR219

$250 \mathrm{mM}$ salinity. The highest biomass values obtained for all salinity levels between salts were $\mathrm{MgSO}_{4}$ (50 and 150) $\mathrm{mM}, \mathrm{MgCl}_{2}(100$ and 200) $\mathrm{mM}$ and $\mathrm{NaCl}(250 \mathrm{mM})$. On the contrary, the least values obtained for all salinity levels between salts were $\mathrm{KCl}(50,150$ and 200$) \mathrm{mM}, \mathrm{NaCl}(100 \mathrm{mM})$ and $\mathrm{MgSO}_{4}(250 \mathrm{mM})$.

Table 5. Mean comparison for effect of $\mathrm{NaCl}, \mathrm{KCl}, \mathrm{MgCl}_{2}$ and $\mathrm{MgSO}_{4}$ on biomass of Oryza sativa L. cv. MR219 seeds

\begin{tabular}{|l|l|l|l|l|}
\hline \multicolumn{5}{|c|}{ Biomass $(\mathbf{g})$} \\
\hline Concentration $(\mathbf{m M})$ & $\mathbf{N a C l}$ & KCl & $\mathbf{M g C l}_{\mathbf{2}}$ & $\mathbf{M g S O}_{\mathbf{4}}$ \\
\hline 0 (control) & $0.017^{\mathrm{a}} \pm 0.001$ & $0.017^{\mathrm{a}} \pm 0.001$ & $0.017^{\mathrm{a}} \pm 0.001$ & $0.0170^{\mathrm{a}} \pm 0.001$ \\
\hline 50 & $0.017^{\mathrm{abc}} \pm 0.000$ & $0.017^{\mathrm{ab}} \pm 0.001$ & $0.02^{\mathrm{cde}} \pm 0.001$ & $0.0229^{\mathrm{ef}} \pm 0.000$ \\
\hline 100 & $0.018^{\mathrm{abcd}} \pm 0.003$ & $0.021^{\mathrm{def}} \pm 0.001$ & $0.022^{\mathrm{ef}} \pm 0.001$ & $0.0221^{\mathrm{ef}} \pm 0.001$ \\
\hline 150 & $0.021^{\mathrm{def}} \pm 0.001$ & $0.021^{\mathrm{de}} \pm 0.002$ & $0.021^{\mathrm{de}} \pm 0.002$ & $0.0228^{\mathrm{ef}} \pm 0.001$ \\
\hline 200 & $0.022^{\mathrm{ef}} \pm 0.001$ & $0.019^{\mathrm{abcde}} \pm 0.002$ & $0.024^{\mathrm{f}} \pm 0.002$ & $0.0212^{\mathrm{de}} \pm 0.002$ \\
\hline 250 & $0.022^{\mathrm{ef}} \pm 0.002$ & - & - & $0.0203^{\mathrm{bcde}} \pm 0.001$ \\
\hline
\end{tabular}

Values are mean \pm standard deviation $(n=6)$. Means within a column that have different superscript letters (a-f) are significant different from each other (Tukey HSD test, $P \leq 0.05$ )

\subsection{Salt-tolerance}

The tolerance of MR219 seeds was studied with four salinities including $\mathrm{NaCl}, \mathrm{KCl}, \mathrm{MgCl}_{2}$ and $\mathrm{MgSO}_{4}$ on different concentrations as shown in Table 6. Rice seeds were tolerant to $\mathrm{NaCl}, \mathrm{KCl}$, $\mathrm{MgCl}_{2}$ and $\mathrm{MgSO}_{4}$ at all salinity levels except $250 \mathrm{mM} \mathrm{KCl}$ and $250 \mathrm{mM} \mathrm{MgCl} 2$. No result was obtained for these concentrations and this suggests that rice seeds were not tolerant to high salinity of $\mathrm{KCl}$ and $\mathrm{MgCl}_{2}$. The highest salt tolerance was found in $200 \mathrm{mM} \mathrm{MgCl} 2(143.3 \%)$ and the lowest in $50 \mathrm{mM} \mathrm{KCl}(100 \%)$. Seeds in $\mathrm{KCl}$ and $\mathrm{MgSO}_{4}$ treatments showed decreasing salt tolerance pattern as salt concentrations increased. Seeds in $\mathrm{NaCl}$ treatments showed increasing salt tolerance pattern from 0-200 $\mathrm{mM}$ but decreased at $250 \mathrm{mM}$ salinity. On the other hand, inconsistent pattern of salt tolerance was observed in $\mathrm{MgCl}_{2}$. Salt tolerance marked increment from 0-100 mM salinity and followed by a drop from 100-150 mM salinity but rise to the highest value at $200 \mathrm{mM}$ salinity.

Table 6. Mean comparison for effect of $\mathrm{NaCl}, \mathrm{KCl}, \mathrm{MgCl}_{2}$ and $\mathrm{MgSO}_{4}$ on salt tolerance of Oryza sativa $\mathrm{L}$. cv. MR219 seeds

\begin{tabular}{|l|l|l|l|l|}
\hline \multicolumn{5}{|l|}{ Salt tolerance (\%) } \\
\hline Concentration $(\mathbf{m M})$ & $\mathbf{N a C l}$ & KCl & $\mathbf{M g C l}_{\mathbf{2}}$ & $\mathbf{M g S O}_{\mathbf{4}}$ \\
\hline 0 (control) & $100.0^{\mathrm{a}} \pm 0.0$ & $100.0^{\mathrm{a}} \pm 0.0$ & $100.0^{\mathrm{a}} \pm 0.0$ & $100.0^{\mathrm{a}} \pm 0.0$ \\
\hline 50 & $103.5^{\mathrm{ab}} \pm 2.3$ & $100.0^{\mathrm{a}} \pm 6.3$ & $120.0^{\mathrm{bcd}} \pm 8.9$ & $135.0^{\mathrm{de}} \pm 5.5$ \\
\hline 100 & $110.7^{\mathrm{abc}} \pm 15.1$ & $126.7^{\mathrm{cde}} \pm 8.2$ & $133.3^{\mathrm{de}} \pm 5.2$ & $130.0^{\mathrm{de}} \pm 8.9$ \\
\hline 150 & $126.7^{\mathrm{cde}} \pm 5.2$ & $123.3^{\mathrm{cd}} \pm 10.3$ & $123.3^{\mathrm{de}} \pm 10.3$ & $133.3^{\mathrm{de}} \pm 5.2$ \\
\hline 200 & $133.3^{\mathrm{de}} \pm 5.2$ & $116.7^{\mathrm{abcd}} \pm 12.1$ & $143.3^{\mathrm{e}} \pm 5.2$ & $126.7^{\text {cde }} \pm 12.1$ \\
\hline 250 & $130.0^{\mathrm{de}} \pm 11.0$ & - & - & $123.3^{\text {cd }} \pm 5.8$ \\
\hline
\end{tabular}

Values are mean \pm standard deviation $(n=6)$. Means within a column that have different superscript letters (a-e) are significant different from each other (Tukey HSD test, $P \leq 0.05$ ).

\subsection{Relative injury rate}

Table 7 depicts that rice seedlings growing in all salts recorded significant $(P \leq 0.05)$ increment in relative injury rate with the increase of salinity levels. However, no significant difference in relative injury rate was observed between control and both $50 \mathrm{mM}$ and $100 \mathrm{mM}$ of all salts. Seeds under $\mathrm{NaCl}$ treatments were observed to have lowest relative injury rate for remaining salinity levels. On the contrary, seeds under $\mathrm{MgSO}_{4}$ treatments recorded the highest relative injury rate value at 50, 100 and $150 \mathrm{mM}$ salt concentrations. Rice seeds was observed to be seriously injured by high salinity (200 $\mathrm{mM})$ in $\mathrm{MgCl}_{2}$ and $(250 \mathrm{mM})$ in $\mathrm{KCl}$. 
Effect of Four Different Salts on Seed Germination and Morphological Characteristics of Oryza sativa L. cV. MR219

Table 7. Mean comparison for effect of $\mathrm{NaCl}, \mathrm{KCl}, \mathrm{MgCl}_{2}$ and $\mathrm{MgSO}_{4}$ on relative injury rate of Oryza sativa $\mathrm{L}$. cv. MR219 seeds

\begin{tabular}{|l|l|l|l|l|}
\hline \multicolumn{7}{|c|}{ Relative injury rate (RIR) } \\
\hline Concentration $(\mathbf{m M})$ & $\mathbf{N a C l}$ & KCl & $\mathbf{M g C l}_{\mathbf{2}}$ & $\mathbf{M g S O}_{4}$ \\
\hline 0 (control) & $0.00^{\mathrm{a}} \pm 0.0$ & $0.00^{\mathrm{a}} \pm 0.0$ & $0.00^{\mathrm{a}} \pm 0.0$ & $0.00^{\mathrm{a}} \pm 0.0$ \\
\hline 50 & $0.06^{\mathrm{abc}} \pm 0.06$ & $0.04^{\mathrm{ab}} \pm 0.04$ & $0.06^{\mathrm{abc}} \pm 0.03$ & $0.09^{\mathrm{abcd}} \pm 0.06$ \\
\hline 100 & $0.15^{\mathrm{abcd}} \pm 0.06$ & $0.17^{\mathrm{abcd}} \pm 0.12$ & $0.06^{\mathrm{abc}} \pm 0.06$ & $0.19^{\mathrm{abcd}} \pm 0.07$ \\
\hline 150 & $0.14^{\mathrm{abcd}} \pm 0.17$ & $0.25^{\mathrm{bcde}} \pm 0.19$ & $0.15^{\mathrm{abcd}} \pm 0.11$ & $0.29^{\text {cdef }} \pm 0.08$ \\
\hline 200 & $0.31^{\text {def }} \pm 0.19$ & $0.46^{\mathrm{efg}} \pm 0.14$ & $0.49^{\mathrm{fg}} \pm 0.06$ & $0.45^{\mathrm{efg}} \pm 0.09$ \\
\hline 250 & $0.49^{\mathrm{fg}} \pm 0.13$ & $0.91^{\mathrm{i}} \pm 0.06$ & $0.77^{\mathrm{hi}} \pm 0.14$ & $0.65^{\mathrm{gh}} \pm 0.07$ \\
\hline
\end{tabular}

Values are mean \pm standard deviation $(n=5)$. Means within a column that have different superscript letters (a-i) are significant different from each other (Tukey HSD test, $P \leq 0.05$ )

\subsection{Seed vigor}

In all salts with different concentrations from $0-250 \mathrm{mM}$, the general trend was associated with significant $(P \leq 0.05)$ decrease of seed vigor (Table 8$). \mathrm{KCl}$ presented the best seed performance at 50 $\mathrm{mM}$ salinity. However, $\mathrm{NaCl}$ still remained to show better performance for the rest of salinity levels as the seedlings under $\mathrm{NaCl}$ treatments were observed to have highest seed vigor values compared to other salts. Since seed vigor value is obtained from the germination percentage, shoot length and root length, the absence of root growth in rice seedlings under all salinity levels of $\mathrm{MgSO}_{4}$ explained the lowest seed vigor values obtained except for $250 \mathrm{mM}$ salinity. Besides, this could illustrate the nonsignificant difference in seed vigor between control and all $\mathrm{MgSO}_{4}$ salt concentrations. At $250 \mathrm{mM}$ salinity, no data was obtained for $\mathrm{KCl}$ and $\mathrm{MgCl}_{2}$ due to the inhibition of root and shoot growth by high salt concentration.

Table 8. Mean comparison for effect of $\mathrm{NaCl}, \mathrm{KCl}, \mathrm{MgCl}_{2}$ and $\mathrm{MgSO}_{4}$ on seed vigor of Oryza sativa L. cv. MR219 seeds

\begin{tabular}{|l|l|l|l|l|}
\hline \multicolumn{5}{|c|}{ Seed vigor } \\
\hline Concentration $(\mathbf{m M})$ & $\mathbf{N a C l}$ & KCl & $\mathbf{M g C l}_{\mathbf{2}}$ & $\mathbf{M g S O}_{\mathbf{4}}$ \\
\hline 0 (control) & $14.5^{\mathrm{a}} \pm 0.3$ & $14.5^{\mathrm{a}} \pm 0.3$ & $14.5^{\mathrm{a}} \pm 0.3$ & $14.5^{\mathrm{a}} \pm 0.3$ \\
\hline 50 & $8.7^{\mathrm{c}} \pm 1.0$ & $11.4^{\mathrm{b}} \pm 2.0$ & $2.7^{\mathrm{def}} \pm 0.7$ & $1.4^{\mathrm{fgh}} \pm 0.7$ \\
\hline 100 & $7.7^{\mathrm{c}} \pm 1.5$ & $3.7^{\mathrm{d}} \pm 0.6$ & $2.1^{\mathrm{efg}} \pm 0.3$ & $0.9^{\mathrm{gh}} \pm 0.2$ \\
\hline 150 & $3.3^{\mathrm{de}} \pm 0.2$ & $1.9^{\mathrm{efg}} \pm 0.4$ & $1.2^{\mathrm{gh}} \pm 0.2$ & $0.8^{\mathrm{gh}} \pm 0.2$ \\
\hline 200 & $1.7^{\mathrm{efgh}} \pm 0.5$ & $0.8^{\mathrm{gh}} \pm 0.2$ & $0.5^{\mathrm{gh}} \pm 0.1$ & $0.6^{\mathrm{gh}} \pm 0.1$ \\
\hline 250 & $1.1^{\mathrm{fgh}} \pm 0.0$ & - & - & $0.2^{\mathrm{h}} \pm 0.1$ \\
\hline
\end{tabular}

Values are mean \pm standard deviation $(\mathrm{n}=5)$. Means within a column that have different superscript letters (a-h) are significant different from each other (Tukey HSD test, $P \leq 0.05$ )

\subsection{Seedling height}

The seedling height reduction was observed to have linear relationship with increasing salt concentration levels. The seedling height reduction was significantly $(P \leq 0.05)$ declined in all treatments due to increasing salinity level as shown in Table 9. Highest seedling height reduction at all salinity levels was found in $\mathrm{MgSO}_{4}$ except $200 \mathrm{mM}$ which was shown in $\mathrm{KCl}$. There was no data shown for $250 \mathrm{mM} \mathrm{KCl}$ and $\mathrm{MgCl}_{2}$ due to seedling growth inhibition by higher salt concentration as mentioned previously. The seedling height was less affected by $\mathrm{NaCl}$ treatment at most salinity levels as least reduction percentages were recorded at all salt concentrations except for $200 \mathrm{mM}$ which was found in $\mathrm{MgCl}_{2}$.

Table 9. Mean comparison for effect of $\mathrm{NaCl}, \mathrm{KCl}, \mathrm{MgCl}_{2}$ and $\mathrm{MgSO}_{4}$ on seedling height reduction of Oryza sativa L. cv. MR219

\begin{tabular}{|l|l|l|l|l|}
\hline \multicolumn{5}{|c|}{ Seedling height reduction (\%) } \\
\hline Concentration $(\mathbf{m M})$ & $\mathbf{N a C l}$ & $\mathbf{K C l}$ & $\mathbf{M g C l}_{\mathbf{2}}$ & $\mathbf{M g S O}_{\mathbf{4}}$ \\
\hline 0 (control) & $0.00^{\mathrm{a}} \pm 0.0$ & $0.00^{\mathrm{a}} \pm 0.0$ & $0.00^{\mathrm{a}} \pm 0.0$ & $0.00^{\mathrm{a}} \pm 0.0$ \\
\hline 50 & $51.9^{\mathrm{b}} \pm 3.6$ & $65.6^{\mathrm{cd}} \pm 2.4$ & $70.2^{\mathrm{de}} \pm 2.1$ & $77.5^{\mathrm{gh}} \pm 0.8$ \\
\hline 100 & $64.7^{\mathrm{c}} \pm 3.5$ & $71.6^{\mathrm{ef}} \pm 2.1$ & $73.0^{\mathrm{efg}} \pm 0.8$ & $84.0^{\mathrm{ijk}} \pm 2.1$ \\
\hline
\end{tabular}

International Journal of Advanced Research in Botany (IJARB)

Page | 36 
Effect of Four Different Salts on Seed Germination and Morphological Characteristics of Oryza sativa L. cV. MR219

\begin{tabular}{|l|l|l|l|l|}
\hline \hline 150 & $76.3^{\mathrm{fg}} \pm 0.8$ & $81.7^{\mathrm{hi}} \pm 0.8$ & $77.5^{\mathrm{gh}} \pm 0.8$ & $85.8^{\mathrm{jk}} \pm 0.8$ \\
\hline 200 & $84.0^{\mathrm{ijk}} \pm 0.8$ & $89.0^{\mathrm{klm}} \pm 1.4$ & $83.5^{\mathrm{ij}} \pm 1.4$ & $88.1^{\mathrm{jkm}} \pm 1.6$ \\
\hline 250 & $87.2^{\mathrm{jkl}} \pm 0.8$ & - & - & $92.7^{\mathrm{m}} \pm 2.1$ \\
\hline
\end{tabular}

Values are mean \pm standard deviation $(n=3)$. Means within a column that have different superscript letters $(a-m)$ are significant different from each other (Tukey HSD test, $P \leq 0.05$ ).

\subsection{Shoot length}

Table 10 depicts that the shoot length of rice seedlings declined in all the salt treatments relative to the increase in salinity. $\mathrm{NaCl}$ showed the longest shoot length compared to other salts at all salinity levels. On the contrary, seedlings under $\mathrm{MgSO}_{4}$ treatment presented shortest shoot length at all salinity levels except for $200 \mathrm{mM}$ salinity which was shown in $\mathrm{KCl}$. High salinity $(250 \mathrm{mM})$ of $\mathrm{KCl}$ and $\mathrm{MgCl}_{2}$ suppressed the shoot growth.

Table 10. Mean comparison for effect of $\mathrm{NaCl}, \mathrm{KCl}, \mathrm{MgCl}_{2}$ and $\mathrm{MgSO}_{4}$ on shoot length of Oryza sativa L. cv. MR219 seedlings

\begin{tabular}{|c|c|c|c|c|}
\hline \multicolumn{5}{|c|}{ Shoot Length $(\mathrm{cm})$} \\
\hline Concentration (mM) & $\mathrm{NaCl}$ & KCl & $\mathrm{MgCl}_{2}$ & $\mathrm{MgSO}_{4}$ \\
\hline 0 (control) & $7.3^{\mathrm{a}} \pm 0.9$ & $7.3^{\mathrm{a}} \pm 0.9$ & $7.3^{\mathrm{a}} \pm 0.9$ & $7.3^{\mathrm{a}} \pm 0.9$ \\
\hline 50 & $3.5^{b} \pm 0.3$ & $2.5^{\mathrm{c}} \pm 0.2$ & $2.2^{\mathrm{cd}} \pm 0.2$ & $1.6^{\operatorname{defg}} \pm 0.1$ \\
\hline 100 & $2.6^{\mathrm{c}} \pm 0.3$ & $2.1^{\mathrm{cd}} \pm 0.2$ & $2.0^{\text {cde }} \pm 0.1$ & $1.2^{\text {fghi }} \pm 0.2$ \\
\hline 150 & $1.7^{\mathrm{def}} \pm 0.1$ & $1.3^{\text {efgh }} \pm 0.1$ & $1.6^{\operatorname{defg}} \pm 0.1$ & $1.0^{\mathrm{fghi}} \pm 0.1$ \\
\hline 200 & $1.2^{\text {fghi }} \pm 0.1$ & $0.8^{\mathrm{hi}} \pm 0.1$ & $1.2^{\text {fghi }} \pm 0.1$ & $0.9^{\mathrm{hi}} \pm 0.1$ \\
\hline 250 & $0.9^{\text {ghi }} \pm 0.1$ & - & - & $0.5^{\mathrm{i}} \pm 0.2$ \\
\hline
\end{tabular}

Values are mean \pm standard deviation $(n=3)$. Means within a column that have different superscript letters (a-i) are significant different from each other (Tukey HSD test, $P \leq 0.05$ )

\subsection{Root length}

Table 11 shows that both $\mathrm{NaCl}$ and $\mathrm{KCl}$ reduced significantly $(P \leq 0.05)$ the root length of rice seedlings with increasing salt concentrations. The highest root length at all salinity levels was observed in $\mathrm{NaCl}$ treatment except for $50 \mathrm{mM}$ salinity which was presented by $\mathrm{KCl}$. The root length was increased by $50 \mathrm{mM} \mathrm{KCl}$ which indicates that this concentration enhances the root growth but the growth was negatively affected by higher salinity especially at $250 \mathrm{mM}$ as the root was inhibited. Also, there was no root growth observed in $\mathrm{MgCl}_{2}$ (except $50 \mathrm{mM}$ ) and $\mathrm{MgSO}_{4}$. Therefore, this proposes that these two salts might have inhibitory effect on the root growth of rice seedlings.

Table 11. Mean comparison for effect of $\mathrm{NaCl}, \mathrm{KCl}, \mathrm{MgCl}_{2}$ and $\mathrm{MgSO}_{4}$ on root length of Oryza sativa L. cv. MR219 seedlings

\begin{tabular}{|l|l|l|l|l|}
\hline \multicolumn{5}{|c|}{ Rot Length $(\mathbf{c m})$} \\
\hline Concentration $(\mathbf{m M})$ & $\mathbf{N a C l}$ & KCl & $\mathbf{M g C l}_{\mathbf{2}}$ & $\mathbf{M g S O}_{\mathbf{4}}$ \\
\hline 0 (control) & $7.3^{\mathrm{a}} \pm 0.8$ & $7.3^{\mathrm{a}} \pm 0.8$ & $7.3^{\mathrm{a}} \pm 0.8$ & $7.3^{\mathrm{a}} \pm 0.8$ \\
\hline 50 & $5.2^{\mathrm{b}} \pm 0.2$ & $8.3^{\mathrm{a}} \pm 0.3$ & $1.0^{\mathrm{de}} \pm 0.3$ & - \\
\hline 100 & $3.5^{\mathrm{c}} \pm 0.6$ & $1.9^{\mathrm{d}} \pm 0.4$ & - & - \\
\hline 150 & $3.4^{\mathrm{c}} \pm 0.1$ & $1.3^{\mathrm{de}} \pm 0.2$ & - & - \\
\hline 200 & $1.9^{\mathrm{d}} \pm 0.2$ & $0.6^{\mathrm{e}} \pm 0.1$ & - & - \\
\hline 250 & $0.7^{\mathrm{e}} \pm 0.3$ & - & - & - \\
\hline
\end{tabular}

Values are mean \pm standard deviation $(n=3)$. Means within a column that have different superscript letters (a-e) are significant different from each other (Tukey HSD test, $P \leq 0.05$ )

\subsection{Leaf length}

Inverse association was observed between leaf length of rice seedlings and salt concentrations. The leaf length of rice seedlings under saline condition was significantly reduced with the increase of salt concentrations for all salts which is depicted in Table 12. Leaf length of rice seedlings under $\mathrm{NaCl}$ treatments at all salinity levels were the longest compared to other salts which indicates that rice seedlings have higher tolerance to $\mathrm{NaCl}$ salinity. The growth of leaf was inhibited at high salinity (250 $\mathrm{mM}$ ) of $\mathrm{KCl}, \mathrm{MgCl}_{2}$ and $\mathrm{MgSO}_{4}$. 
Effect of Four Different Salts on Seed Germination and Morphological Characteristics of Oryza sativa L. cv. MR219

Table 12. Mean comparison for effect of $\mathrm{NaCl}, \mathrm{KCl}, \mathrm{MgCl}_{2}$ and $\mathrm{MgSO}_{4}$ on leaf length of Oryza sativa L. $\mathrm{cv}$. MR219 seedlings

\begin{tabular}{|l|l|l|l|l|}
\hline \multicolumn{5}{|c|}{ Leaf Length $(\mathbf{c m})$} \\
\hline Concentration $(\mathbf{m M})$ & NaCl & KCl & $\mathbf{M g C l}_{\mathbf{2}}$ & MgSO $_{\mathbf{4}}$ \\
\hline 0 (control) & $5.8^{\mathrm{a}} \pm 0.6$ & $5.8^{\mathrm{a}} \pm 0.6$ & $5.8^{\mathrm{a}} \pm 0.6$ & $5.8^{\mathrm{a}} \pm 0.6$ \\
\hline 50 & $4.8^{\mathrm{ab}} \pm 0.6$ & $3.4^{\mathrm{bcd}} \pm 1.3$ & $3.5^{\mathrm{bcd}} \pm 0.3$ & $3.5^{\mathrm{bcd}} \pm 0.2$ \\
\hline 100 & $3.9^{\mathrm{bc}} \pm 0.9$ & $2.2^{\mathrm{def}} \pm 0.5$ & $2.1^{\mathrm{defg}} \pm 0.2$ & $2.6^{\mathrm{cde}} \pm 0.4$ \\
\hline 150 & $3.1^{\mathrm{cd}} \pm 0.2$ & $1.3^{\mathrm{efg}} \pm 0.1$ & $1.1^{\mathrm{efg}} \pm 0.2$ & $1.1^{\mathrm{fg}} \pm 0.3$ \\
\hline 200 & $1.6^{\mathrm{efg}} \pm 0.5$ & $0.6^{\mathrm{g}} \pm 0.0$ & $0.6^{\mathrm{g}} \pm 0.1$ & $0.7^{\mathrm{g}} \pm 0.2$ \\
\hline 250 & $1.1^{\mathrm{fg}} \pm 0.4$ & - & - & - \\
\hline
\end{tabular}

Values are mean \pm standard deviation $(\mathrm{n}=3)$. Means within a column that have different superscript letters $(\mathrm{a}-\mathrm{g})$ are significant different from each other (Tukey HSD test, $P \leq 0.05$ )

Morphological characteristics of Oryza sativa L. cv. MR 219 treated with different salt types $(\mathrm{NaCl}$, $\mathrm{KCl}, \mathrm{MgCl}_{2}$ and $\mathrm{MgSO}_{4}$ ) at different salinity levels $(50,100,150,200$ and 250) $\mathrm{mM}$ are shown in Figure 3 and 4. In brief, rice seedlings responded differently to different salinity. It was observed that high salinity at $250 \mathrm{mM} \mathrm{KCl}, \mathrm{MgCl}_{2}$ and $\mathrm{MgSO}_{4}$ negatively affected the germination of rice seeds. This suggests that rice seeds are susceptible to high salinity of these salts. On the other hand, rice seeds are more tolerant to $\mathrm{NaCl}$ salinity as they are able to germinate even at the highest salt concentration $(250 \mathrm{mM})$.

Besides, effect of salinity on growth condition, leaf color and leaf symptom of Oryza sativa L. cv. MR 219 is presented in Table 13.

Table 13. Growth condition, leaf color and leaf symptom of rice seedlings at different salinity levels of $\mathrm{NaCl}$, $\mathrm{KCl}, \mathrm{MgCl}_{2}$ and $\mathrm{MgSO}_{4}$ at Day 14 .

\begin{tabular}{|c|c|c|c|}
\hline Treatment & Growth Condition & Color of leaf & Leaf symptom \\
\hline control & Normal & Green & Healthy \\
\hline \multicolumn{4}{|c|}{$\mathrm{NaCl}$} \\
\hline 50 & Normal & Green & Healthy \\
\hline 100 & Normal & Green & Healthy \\
\hline 150 & Moderate & Slightly yellow & Necrosis \\
\hline 200 & Less & Slightly yellow & Necrosis \\
\hline 250 & Less & Not completely developed & - \\
\hline \multicolumn{4}{|c|}{ KCl } \\
\hline 50 & Normal & Slightly yellow & Rolled \\
\hline 100 & Normal & Slightly yellow & Rolled \\
\hline 150 & Moderate & Slightly yellow & Necrosis \\
\hline 200 & Moderate & Slightly yellow & Necrosis \\
\hline 250 & Retarded & - & - \\
\hline \multicolumn{4}{|c|}{$\mathrm{MgCl}_{2}$} \\
\hline 50 & Normal & Green & Rolled \\
\hline 100 & Abnormal, root growth is inhibited & Slightly yellow & Shrink and rolled \\
\hline 150 & Abnormal, root growth is inhibited & Slightly yellow & Shrink and rolled \\
\hline 200 & Abnormal, root growth is inhibited & Yellow & Shrink and rolled \\
\hline 250 & Abnormal, root growth is inhibited & - & - \\
\hline \multicolumn{4}{|c|}{$\mathrm{MgSO}_{4}$} \\
\hline 50 & Abnormal, root growth is inhibited & Green & Rolled \\
\hline 100 & Abnormal, root growth is inhibited & Green & Shrink and rolled \\
\hline 150 & Abnormal, root growth is inhibited & Slightly yellow & Shrink and rolled \\
\hline 200 & Abnormal, root growth is inhibited & Slightly yellow & Shrink and rolled \\
\hline 250 & Abnormal, root growth is inhibited & Not completely developed & - \\
\hline
\end{tabular}




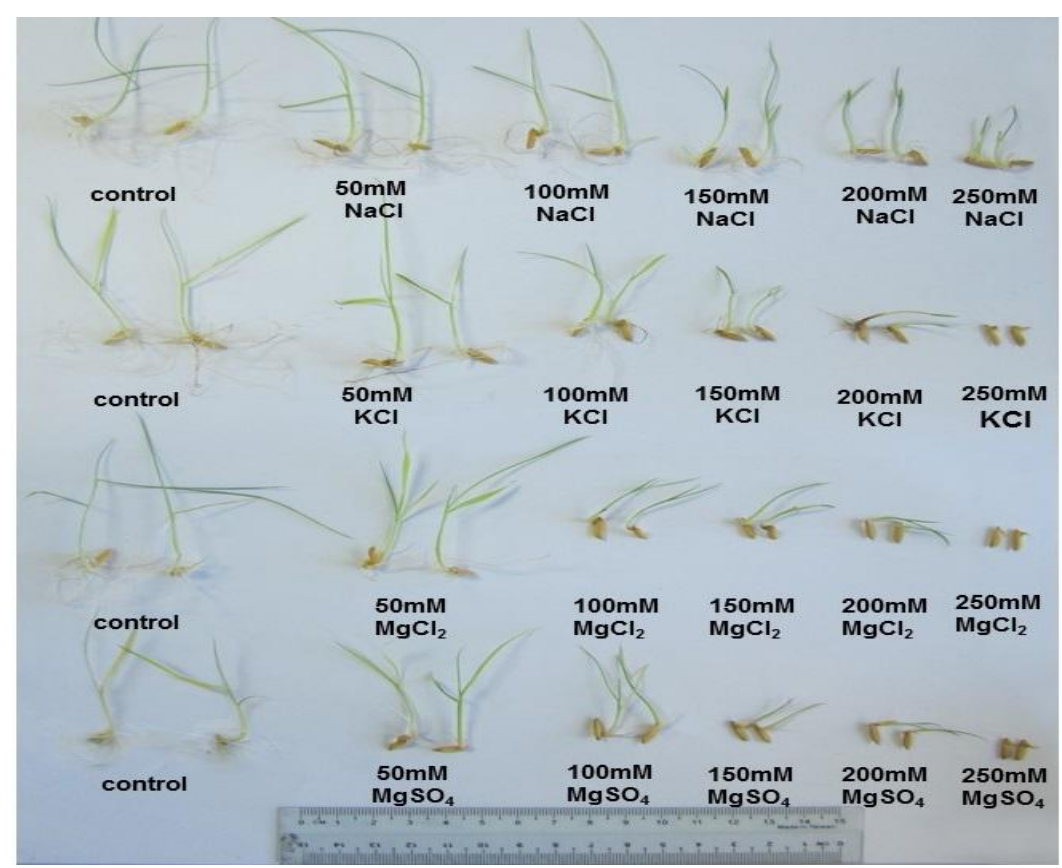

Figure 3. $\mathrm{MR} 219$ seeds germination in different saline solutions of $\mathrm{NaCl}, \mathrm{KCl}, \mathrm{MgCl}_{2}$ and $\mathrm{MgSO}_{4}$ on different concentrations (50, 100, 150, 200 and 250) mM at Day 14.

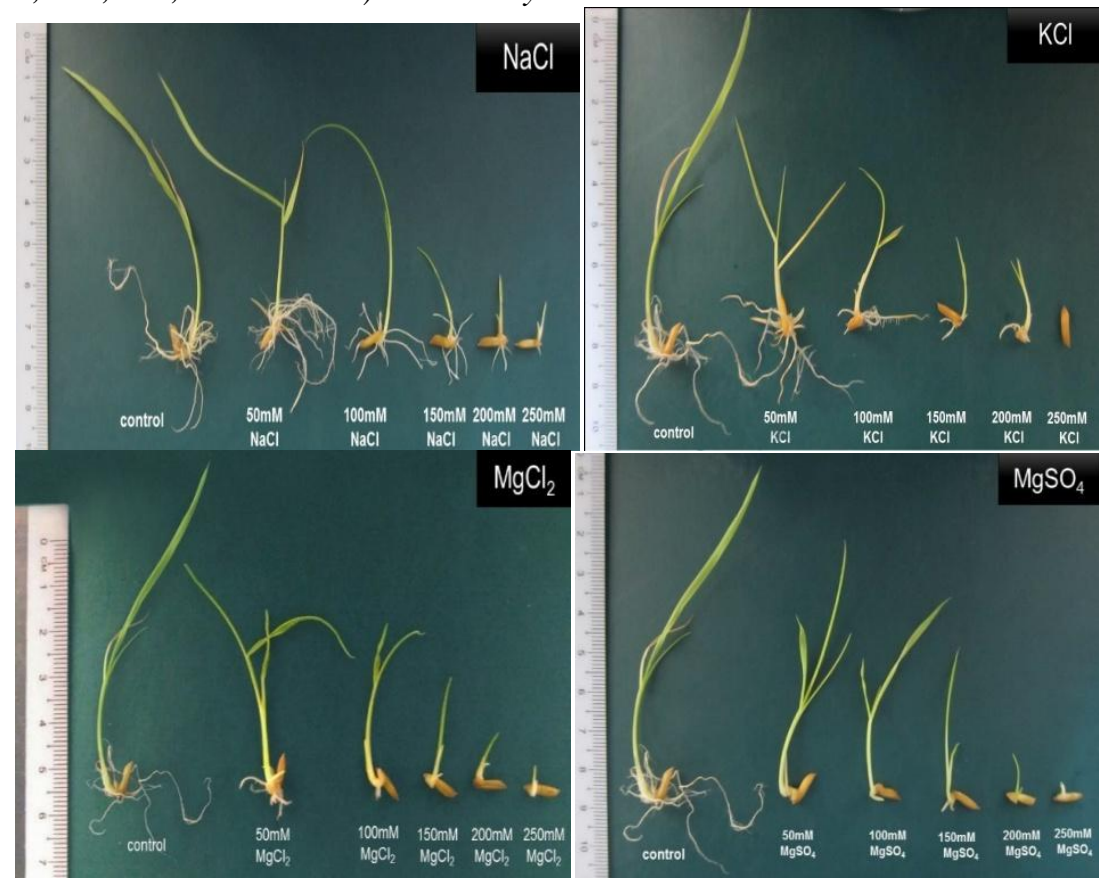

Figure 4. Morphological observation of $\mathrm{MR2} 19$ seedlings in different salt types ( $\mathrm{NaCl}, \mathrm{KCl}, \mathrm{MgCl}_{2}$ and $\mathrm{MgSO}_{4}$ ) on different concentrations (50, 100, 150, 200 and 250) mM at Day 14.

\section{DISCUSSION}

Due to the preponderance in saline atmosphere, $\mathrm{NaCl}$ has been used widely in studying seed germination of many plants (Zehra et al., 2013). However, the effect of other salts on seed germination has become the great interest of researches recently in improving salt tolerance lines. In present study, the effects of $\mathrm{NaCl}, \mathrm{KCl}, \mathrm{MgCl}_{2}$ and $\mathrm{MgSO}_{4}$ on seed germination and early seedling growth of Oryza sativa L. cv. MR219 were compared. The findings showed clearly that rice seeds responded significantly to different salinity levels of different salts.

\subsection{Effect of salts on germination of MR219 seeds}

In general, saline soils are made up of various salts with varying impacts on seed germination (Tobe et al., 2003). Differential behaviours of seeds are normally observed in different plant species in 
Effect of Four Different Salts on Seed Germination and Morphological Characteristics of Oryza sativa L. cV. MR219

response to different salt components (Tobe et al., 2004). In fact, the inhibitory effect on reduced seed germination of most plants can be explained by osmotic and ionic effects (Afzali et al., 2011; Zehra et al., 2013; Rajpar et al., 2016). Osmotic effect due to salinity reduced seed germination which brings adverse impacts on the activity of important enzymes such as $\alpha$ amylase, RNAse and protease in the endosperm. Water uptake imbalance restricts the hydrolysis of food reserves and ultimately immobilizes translocation of food reserve from storage tissue to developing embryo (Deivanai et al., 2011). In our finding, the water uptake percentage of MR219 seeds decreased with increasing salt concentrations. The result obtained is similar to the finding from salinity study of wheat (M. Rahman et al., 2008) and Bean (Kaymakanova, 2009). Momayezi et al. (2009) reported that the reduction of water content with increasing salt concentrations in Japonica rice varieties (Shafag and Fajr).

Low water availability caused reduction in nutrition uptake and carbon metabolisms under osmotic stress, resulting in the decrease of germination rate.Furthermore, Tobe et al. (2003) stated that seeds with salt-permeable coat that are growing in saline condition could lose their germinability. However, for certain species, the embryo will be protected by seed coat before germination but once it protrudes out from the coat, injury happens. Pradheeban et al. (2015) explained that high intracellular concentrations of $\mathrm{Na}^{+}$and $\mathrm{Cl}^{-}$suppresses the metabolism of dividing and expanding cells which subsequently inhibits germination. According to Zehra et al. (2013), potassium serves as important agent in osmotic adjustment and specific metabolic agent in protein and starch synthesis and enzyme activation. However, higher $\mathrm{K}^{+}$concentration would lead to $\mathrm{K}^{+}$toxicity which brings deleterious effect on seed germination. It is hypothesized that this ion may not be able to transport across membrane and the accumulation causes specific ion toxicity in external milieu which blocks many metabolic functions. Different forms of chlorides have different natures to affect growth and development of plants but $\mathrm{NaCl}$ could be more toxic to plants compared to chlorides of other salts. Also, accumulation of $\mathrm{Mg}^{2+}$ during germination and early seedling growth caused abnormalities in rice seedlings under treatments with $\mathrm{Mg}^{2+}$ salts $\left(\mathrm{MgCl}_{2}\right.$ and $\left.\mathrm{MgSO}_{4}\right)$ even at low salinity levels. Tobe et al. (2002) found that $\mathrm{MgCl}_{2}$ were more toxic than $\mathrm{NaCl}$ and $\mathrm{KCl}$ in seed germination study of nonhalophytes.

The finding of study showed that $\mathrm{NaCl}, \mathrm{KCl}, \mathrm{MgCl}_{2}$ and $\mathrm{MgSO}_{4}$ had negative effects on the MR219 seed germination percentage. Among the four salts, $\mathrm{NaCl}$ was found to have better germination even in the highest $250 \mathrm{mM}$ salinity level. On the other hand, MR219 seeds under $\mathrm{KCl}$ and $\mathrm{MgCl}_{2}$ treatments were observed to germinate less at the highest salinity level which suggested that MR219 rice seeds have low tolerance to high salinity levels of these salts. This agrees with other observations in bean (Kaymakanova, 2009), spinach (Turhan et al., 2011), halophyte quinoa (Panuccio et al., 2014) and other rice cultivars such as 'Dongjin' and Kumnam (Sohn et al., 2005), Shaheen Basmati, Basmati-385 and NIABIR 9 (Jamil et al., 2012) and NERICA, IR, IWA and POKKALLI (Ologundudu et al., 2014).

Both mean germination time (MGT) and germination index (GI) can enhance the seed tolerance to salinity stress during germination stage. Normally, salt-tolerant genotypes express the lowest MGT and the highest GI(Momayezi et al., 2009). The present finding showed that germination index of rice seedlings under $\mathrm{NaCl}, \mathrm{KCl}, \mathrm{MgCl}_{2}$ and $\mathrm{MgSO}_{4}$ reduced at higher salinity levels. $\mathrm{MgCl}_{2}$ treatments at low salinity ( $50 \mathrm{mM}$ and $100 \mathrm{mM}$ ) showed the highest germination index but $\mathrm{NaCl}$ treatments were observed to have the highest germination index at high salinity levels $(150-250 \mathrm{mM})$. Previous research by $\mathrm{Li}(2008)$ demonstrated that germination index of $L$. sinense and $G$. soja decreased significantly in relative to control and increasing salt concentrations. On the contrary, $\mathrm{NaCl}, \mathrm{KCl}$, $\mathrm{MgCl}_{2}$ and $\mathrm{MgSO}_{4}$ delayed mean germination time of rice seeds. This findings are similar with study by (Turhan et al., 2011) in spinach and (Tsegay \& Gebreslassie, 2014) in Lathyrus sativus and Pisum sativum var. abyssinicum.

Seed vigor is characterized as a potential determinant for rapid and uniform seedling emergence and crops establishment(Mondo et al., 2013). According to Heydecker (1972), vigour means tantamount to the seed property that shows good performance. In the study, it was found that seed vigor of MR219 seeds was inversely related to salt concentrations. All rice seedlings under all salt treatments experienced decreased seed vigour in relative to increasing salt concentrations. Similarly, Jing et al. (2007) reported the decrease in vigour (length and weight) of rice cultivar "Huanghuazhan" seedlings 
Effect of Four Different Salts on Seed Germination and Morphological Characteristics of Oryza sativa L. cV. MR219

under lead stress. However, Sudharani et al. (2012) explained that rice cultivars show different response in their growth rate with the most vigorous lines being the traditional varieties.

Relative injury rate is used to determine the degree of injury on seed of any plants during germination stage which is caused by the salinity. All salts caused the increment in relative injury rate of MR219 rice seedlings which is in parallel with findings of Tsegay and Gebreslassie (2014) in Lathyrus sativus and Pisum sativum var. abyssinicum. It was reported that seeds under $\mathrm{NaCl}$ treatments were less injured compared to other salts as the relative injury rate at all concentrations were less even at the highest $250 \mathrm{mM}$ salinity.

Despite the tolerance during germination, salinity normally delays the emergence in most plants (Läuchli \& Grattan, 2007). However, the response of crop plants to salinity during germination stage differs greatly among crops and variations. Rice is considered as salt-sensitive plant (Flowers and Yeo, 1981) but the sensitivity to salinity varies from one growth stage to the next (Almeida et al., 2016). R. Singh et al. (2009) reported that rice shows tolerance during germination but becomes susceptible to salinity during early seedling development.Lee et al. (2004) introduced a salt stress index that takes into account several factors such as level of salinity, duration of exposure and timing of exposure since the response of rice to salinity is the combination of these factors. Salt tolerance screening at germination offers little basis for further crop salt tolerance assessment because most of the germination studies are conducted in laboratory with Petri-dish like containers moisturized with solutions of varying salinity levels. The authors also explained that there are uncontrolled variables such as seed viability, dormancy, seed coat pre-treatment and water permeability might have influence on seed germination (Läuchli \& Grattan, 2007).

\subsection{Effect of salts on morphological characteristics of seedlings at early growth stage}

Salinity had considerable effects on seedling height of plants. It is common to observe reduction in seedling height in many crop plants grown in saline atmosphere (Hakim et al., 2010). According to Läuchli and Grattan (2007), cells undergo dehydration and shrink moments after salinization but their original volume is regained after few hours. However, salinity leads to reduction in cell elongation and cell division which eventually results in slower leaf appearance and size. The injury symptoms become more obvious after weeks when lateral shoot development is negatively affected and finally overall growth of salt-stressed plants can be clearly differentiated from non-stressed plants. The current study demonstrated that seedling height reduction (\%) increased significantly especially at 250 $\mathrm{mM}$ of $\mathrm{KCl}, \mathrm{MgCl}_{2}$ and $\mathrm{MgSO}_{4}$ as the percentage shown nearly achieved $100 \%$ reduction. The results showed that shoot lengths of all salts at the highest salinity levels were considered severely affected especially in $\mathrm{MgCl}_{2}$. However, rice seedlings under low $\mathrm{NaCl}$ salinity level were still able to produce longer shoot compared to others. Islam and Karim (2010), found that the seedling height reduced with the increase in salinity levels. Overall, $\mathrm{NaCl}$ treatments experienced less seedling height reduction in all salinity levels which proposes more tolerant to $\mathrm{NaCl}$ salinity compared to other salts. Several previous studies also reported that salinity led to reduction in shoot and root length in seedlings of different rice cultivars such as IR, BR, Pokkali and MR rice (Hakim et al., 2010) and IR, MD, PMK, Jeeraga samba, ADT, CO and TKM (Anbumalarmathi et al., 2013).

It is noteworthy that plants adapt saline environment by developing the ability to prevent the influx of $\mathrm{Na}^{+}$from roots to the leaves as extremely high sodium content potentially disturbs nutrient balance and osmotic regulation which subsequently leads to specific ion toxicity (Sohn et al., 2005). Minutes after salinization, osmotic stress arises outside the root that leads to changes in cell-water relations (Läuchli \& Grattan, 2007). Initially osmotic effect reduces plant ability to absorb water as the homeostasis in water status of plants exposed to salinity is negatively disturbed (Nozulaidi et al., 2015). Basically, chloride ions are found abundant in shoots whereas sodium ions are concentrated in roots (Afzali et al., 2011). However, extremely high $\mathrm{Na}^{+}$accumulation in saline soils lowers water potential of plants which makes them unable to regain the turgor from soil osmotic stress (Ologundudu et al., 2014). The loss of turgor in plants due to soil salinity potentially inhibits plant growth as well as provoking stomatal closure and reducing photosynthesis (Amirjani, 2010). Jamil et al. (2012) explained that disturbance in mineral supply due to specific ion effect might have direct impact on plant growth. The increase in $\mathrm{Na}^{+}$ion content and decrease in $\mathrm{K}^{+}$ion uptake results in ionic imbalance as there is direct competition between these two ions, inhibition of $\mathrm{Na}^{+}$on $\mathrm{K}^{+}$transport process in vascular tissues and $\mathrm{Na}^{+}$induced $\mathrm{K}^{+}$efflux from roots. Also, (Hakim et al., 2014) explained 
that ion antagonism was formed once nutritional imbalance was created due to salinity. $\mathrm{Na}^{+}$increased proportionally to different salinity levels in both root and shoot but the rate of increase was higher in root. Therefore, ionic ratios are important keys to determine the relative toxicities that could provide relative biological processes rates under specific ionic antagonisms. In fact, it is vital to maintain high $\mathrm{K}^{+} / \mathrm{Na}^{+}$in many species instead of maintaining low concentration of $\mathrm{Na}^{+}$(Afzali et al., 2011). In addition, the presence of sulfate anion, $\mathrm{SO}_{4}{ }^{2-}$ is believed to enhance the suppressive effect on normal root growth because root growth of rice seedlings were completely inhibited at all salt levels of $\mathrm{MgSO}_{4}$ compared to $\mathrm{MgCl}_{2}$ treatments. Kobayashi et al. (2005) demonstrated that low $\mathrm{MgCl}_{2}$ concentrations reduced growth in rice but high concentrations possibly cause threats to plant growth and viability. Brandenburg and Kleier (2011) also found that chlorosis occurred in radish under 0.01 $\mathrm{M} \mathrm{MgCl} 2$ treatment. However, the present finding could suggest that the combined ions of $\mathrm{Mg}^{2+}$ and $\mathrm{SO}_{4}{ }^{2-}$ exhibit more toxic effects on the normal growth of rice seedlings during germination compared to $\mathrm{MgCl}_{2}$. Presumably, this suppressive effect of $\mathrm{MgSO}_{4}$ could influence the subsequent development of seedlings because absence of root as the tool of water and mineral absorption leads to death of seedlings in the end.On the other hand, the effects of $\mathrm{MgCl}_{2}$ and $\mathrm{MgSO}_{4}$ on root length of rice seedlings were more significant especially $\mathrm{MgSO}_{4}$. The root growth of rice seedlings under $\mathrm{MgSO}_{4}$ was suppressed in all salt levels whereas there was only root growth observed at low $\mathrm{MgCl}_{2}$ concentration $(50 \mathrm{mM})$. The present finding depicted that salinity led to reduction of root growth of rice seedlings but the degree of influence in $\mathrm{NaCl}$ treatments was less compared to other salts. Surprisingly, rice seedlings under $50 \mathrm{mM} \mathrm{KCl}$ attained longer root length in relative to control which suggests that this salt concentration enhanced root growth. However, the extent of root growth reduced drastically from $100-200 \mathrm{mM}$ and even inhibited at $250 \mathrm{mM}$ salinity level. Root elongation is more sensitive to stress and is injured more seriously compared to shoot growth due to inhibitory effect by salts (Hakim et al., 2010). However, the finding was in contrast with those reported by Pradheeban et al. (2015) who explained that the negative effect of salinity on shoot was more noticeable compared to root growth. Besides, Deivanai et al. (2011) stated that the inhibitory effect of salinity on root and shoot growth of rice seedling differs remarkably between cultivars.

Salinity symptoms are normally observed clearly on the first and second leaf. They are described as leaf rolling, formation of new leaf, brownish and whitish leaf tip, drying of leaves and also reduction in root growth, stunted growth and stem thickness which eventually causes complete cessation of growth and dying of seedlings (Sudharani et al., 2012). If remarkable amount of salts enters plants, the salt levels might increase beyond their normal value and reach toxic level in leaves (Sudharani et al., 2012). Consequently, premature senescence and reduced photosynthetic leaf area happen and thus influences the overall carbon balance for normal growth (Läuchli \& Grattan, 2007). If the condition turns worse with more salt accumulation in leaf, the building up of salt concentration in cytoplasm results in leaf injury and mortality.

\section{CONCLUSION}

Different salts caused various effects on germination and the growth of Oryza sativa L. cv. MR219 seedling stage. The seeds were more tolerance to $\mathrm{NaCl}$ compared to $\mathrm{KCl}, \mathrm{MgCl}_{2}$ and $\mathrm{MgSO}_{4}$ that showed similar tolerance during germination. High level of salinity leads to reduction in water uptake percentage, germination percentage and germination index but increased the mean germination time of the seeds. Apart from that, biomass and relative injury rate of seeds increased in relative to control. Seed vigor, seedling height, shoot length, root length and leaf length were negatively affected by increasing salt concentrations. Degree of tolerance of MR219 seeds to salts from morphological results is $\mathrm{NaCl}>\mathrm{KCl}>\mathrm{MgCl} 2>\mathrm{MgSO} 4 . \mathrm{MgCl}_{2}$ and $\mathrm{MgSO}_{4}$ were suggested to have inhibitory effect on root growth of the seedlings.

\section{ACKNOWLEDGEMENTS}

The authors would like to acknowledge to Universiti Putra Malaysia for the research grants, PUTRA GRANT- IPS- 9446700 for financial support.

\section{REFERENCES}

Abdul-Baki, A. A., \& Anderson, J. D. (1973). Vigor determination in soybean seed by multiple criteria. Crop Science, 13(6), 630-633.

Afzali, S., Shariatmadari, H., \& Hajabbasi, M. (2011). Sodium chloride effects on seed germination, growth and ion concentration in chamomile (Matricaria chamomilla). Iran Agricultural Research, 29(2), 107-118. 
Effect of Four Different Salts on Seed Germination and Morphological Characteristics of Oryza sativa L. cv. MR219

Almeida, D. M., Almadanim, M. C., Lourenço, T., Abreu, I. A., Saibo, N. J., \& Oliveira, M. M. (2016). Screening for abiotic stress tolerance in Rice: salt, cold, and drought. Environmental Responses in Plants: Methods and Protocols, 155-182.

Amirjani, M. R. (2010). Effect of $\mathrm{NaCl}$ on some physiological parameters of rice. Eur J Biol Sci, 3(1), 6-16.

Anbumalarmathi, J., Mehta, P., Nethralaya, S., \& Nadu, T. (2013). Effect of salt stress on germination of indica rice varieties. EJBS, 6(1), 1-6.

Brandenburg, W., \& Kleier, C. (2011). Effect of $\mathrm{MgCl} 2$ on Germination, Growth and Biomass Allocation of the Radish CV. American Journal of Environmental Sciences, 7(2), 132.

Carpýcý, E., Celýk, N., \& Bayram, G. (2009). Effects of salt stress on germination of some maize (Zea mays L.) cultivars. African Journal of Biotechnology, 8(19).

Deivanai, S., Xavier, R., Vinod, V., Timalata, K., \& Lim, O. (2011). Role of exogenous proline in ameliorating salt stress at early stage in two rice cultivars. Journal of Stress Physiology \& Biochemistry, 7(4).

Ellis, R., \& Roberts, E. (1981). The quantification of ageing and survival in orthodox seeds. Seed Science and Technology (Netherlands).

Gairola, K., Nautiyal, A., \& Dwivedi, A. (2011). Effect of temperatures and germination media on seed germination of Jatropha curcas Linn. Adv Biores, 2, 66-71.

Gupta, B., \& Huang, B. (2014). Mechanism of salinity tolerance in plants: physiological, biochemical, and molecular characterization. International journal of genomics, 2014.

Hakim, M., Juraimi, A., Hanafi, M., Ismail, M., Rafii, M., Islam, M., \& Selamat, A. (2014). The effect of salinity on growth, ion accumulation and yield of rice varieties. Journal of Animal and Plant Sciences, 24(3), 874-885.

Hakim, M., Juraimi, A. S., Begum, M., Hanafi, M., Ismail, M. R., \& Selamat, A. (2010). Effect of salt stress on germination and early seedling growth of rice (Oryza sativa L.). African Journal of Biotechnology, 9(13), 1911-1918.

Hasanuzzaman, M., Nahar, K., \& Fujita, M. (2013). Plant response to salt stress and role of exogenous protectants to mitigate salt-induced damages Ecophysiology and responses of plants under salt stress (pp. 25-87): Springer.

He, D., \& Yang, P. (2013). Proteomics of rice seed germination. Frontiers in plant science, 4, 246.

Heydecker, W. (1972). Vigour Viability of seeds (pp. 209-252): Springer.

Htwe, N. N., Maziah, M., Ling, H. C., Zaman, F. Q., \& Zain, A. M. (2011). Responses of some selected Malaysian rice genotypes to callus induction under in vitro salt stress. African Journal of Biotechnology, 10(3), 350-362.

Islam, M., \& Karim, M. (2010). Evaluation of Rice (Oryza sativa L.) Genotypes at germination and early seedling stage for their tolerance to salinity. The agriculturists, 8(2), 57-65.

Jaarsma, R., de Vries, R. S., \& de Boer, A. H. (2013). Effect of salt stress on growth, Na+ accumulation and proline metabolism in potato (Solanum tuberosum) cultivars. PloS one, 8(3), e60183.

Jamil, M., Bashir, S., Anwar, S., Bibi, S., Bangash, A., Ullah, F., \& Rha, E. S. (2012). Effect of salinity on physiological and biochemical characteristics of different varieties of rice. Pak J Bot, 44, 7-13.

Jing, C., Cheng, Z., LI, L.-p., SUN, Z.-y., \& PAN, X.-b. (2007). Effects of exogenous salicylic acid on growth and $\mathrm{H} 2 \mathrm{O} 2$-metabolizing enzymes in rice seedlings under lead stress. Journal of Environmental sciences, 19(1), 44-49.

Kandil, A., Sharief, A., \& Ahmed, S. (2012). Germination and seedling growth of some chickpea cultivars (Cicer arietinum L.) under salinity stress. Journal of Basic \& Applied Sciences, 8, 561-571.

Kaymakanova, M. (2009). Effect of salinity on germination and seed physiology in bean (Phaseolus vulgaris L.). Biotechnology \& Biotechnological Equipment, 23(sup1), 326-329.

Khan, M., Hamid, A., \& Karim, M. (1997). Effect of sodium chloride on germination and seedling characters of different types of rice (Oryza sativa L.). Journal of Agronomy and Crop Science, 179(3), 163-169.

Kobayashi, H., Masaoka, Y., \& Sato, S. (2005). Effects of excess magnesium on the growth and mineral content of rice and Echinochloa. Plant production science, 8(1), 38-43.

Läuchli, A., \& Grattan, S. (2007). Plant growth and development under salinity stress Advances in molecular breeding toward drought and salt tolerant crops (pp. 1-32): Springer.

Lee, Y., Park, S., Park, H., \& Kwon, Y. (2004). Salt stress magnitude can be quantified by integrating salinity with respect to duration. Paper presented at the Proceedings of $4^{\text {th }}$ International Crop Sci Congress. Brisbane, Aust. 
Effect of Four Different Salts on Seed Germination and Morphological Characteristics of Oryza sativa L. cv. MR219

Li, Y. (2008). Effect of salt stress on seed germination and seedling growth of three salinity plants. Pakistan journal of biological sciences, 11(9), 1268-1272.

Luan, Z., Xiao, M., Zhou, D., Zhang, H., Tian, Y., Wu, Y., Guan, B., \& Song, Y. (2014). Effects of salinity, temperature, and polyethylene glycol on the seed germination of sunflower (Helianthus annuиs L.). The Scientific World Journal, 2014.

Molassiotis, A., Sotiropoulos, T., Tanou, G., Kofidis, G., Diamantidis, G., \& Therios, E. (2006). Antioxidant and anatomical responses in shoot culture of the apple rootstock $\mathrm{MM} 106$ treated with $\mathrm{NaCl}, \mathrm{KCl}$, mannitol or sorbitol. Biologia Plantarum, 50(1), 61-68.

Momayezi, M. R., Abdul Rahman, Z., Musa, M. H., \& Ismail, M. R. (2009). Seed germination and proline accumulation in rice (Oryza sativa L.) as affected by salt concentrations. Pertanika Journal of Tropical Agricultural Science, 32(2), 247-259.

Mondo, V. H. V., Cicero, S. M., Dourado-Neto, D., Pupim, T. L., \& Dias, M. A. N. (2013). Seed vigor and initial growth of corn crop. Journal of Seed Science, 35(1), 64-69.

Nozulaidi, M., Khairi, M., \& Jahan, M. S. (2015). Effects of different salinity levels on rice production. Aust J Basic Appl Sci, 9, 524-530.

Ologundudu, A. F., Adelusi, A. A., \& Akinwale, R. O. (2014). Effect of Salt Stress on Germination and Growth Parameters of Rice. Notulae Scientia Biologicae, 6(2), 237.

Panuccio, M., Jacobsen, S.-E., Akhtar, S. S., \& Muscolo, A. (2014). Effect of saline water on seed germination and early seedling growth of the halophyte quinoa. AoB Plants, 6, plu047.

Pradheeban, L., Nissanka, N., \& Suriyagoda, L. (2015). Clustering of Rice (Oryza sativa L.) Varieties Cultivated in Jaffna District of Sri Lanka based on Salt Tolerance during Germination and Seedling Stages. Tropical Agricultural Research, 25(3).

Rahman, M., Soomro, U., Haq, M. Z.-u., \& Gul, S. (2008). Effects of NaCl salinity on wheat (Triticum aestivum L.) cultivars. World Journal of Agricultural Sciences, 4(3), 398-403.

Rahman, M. S., Miyake, H., \& Takeoka, Y. (2001). Effect of Sodium Chloride Salinity on Seed Germination and Early Seedling Growth of Rice (Oryza sativa L.). Pak J Bot.

Rajpar, I., Sultan, M., Depar, N., \& Kharal, M. (2016). Tolerance of barley (Hordium vulgare L.) to chlorides of sodium, calcium and magnesium. Pakistan Journal of Agriculture, Agricultural Engineering and Veterinary Sciences (Pakistan).

Singh, J., Sastry, E. V. D., \& Singh, V. (2012). Effect of salinity on tomato (Lycopersicon esculentum Mill.) during seed germination stage. Physiology and molecular biology of plants : an international journal of functional plant biology, 18(1), 45-50. doi: 10.1007/s12298-011-0097-z

Singh, R., Redoña, E., \& Refuerzo, L. (2009). Varietal improvement for abiotic stress tolerance in crop plants: special reference to salinity in rice Abiotic Stress Adaptation in Plants (pp. 387-415): Springer.

Sohn, Y. G., Lee, B. H., Kang, K. Y., \& Lee, J. J. (2005). Effects of NaCl stress on germination, antioxidant responses, and proline content in two rice cultivars. Journal of Plant Biology, 48(2), 201-208.

Sudharani, M., Reddy, P. R., \& Jayalakshmi, V. (2012). A Comprehensive Review on “Genetic Components Of Salinity Tolerance in Rice (Oryza sativa L.)". Int J Appl Biol Pharm Technol, 3, 312-322.

Teh, C. Y., Mahmood, M., Shaharuddin, N. A., \& Ho, C. L. (2014). In vitro rice shoot apices as simple model to study the effect of $\mathrm{NaCl}$ and the potential of exogenous proline and glutathione in mitigating salinity stress. Plant Growth Regulation, 75(3), 771-781.

Tobe, K., Li, X., \& Omasa, K. (2002). Effects of sodium, magnesium and calcium salts on seed germination and radicle survival of a halophyte, Kalidium caspicum (Chenopodiaceae). Australian Journal of Botany, 50(2), 163-169.

Tobe, K., Li, X., \& Omasa, K. (2004). Effects of five different salts on seed germination and seedling growth of Haloxylon ammodendron (Chenopodiaceae). Seed Science Research, 14(04), 345-353.

Tobe, K., Zhang, L., \& Omasa, K. (2003). Alleviatory effects of calcium on the toxicity of sodium, potassium and magnesium chlorides to seed germination in three non-halophytes. Seed Science Research, 13(01), 4754.

Tsegay, B. A., \& Gebreslassie, B. (2014). The effect of salinity $(\mathrm{NaCl})$ on germination and early seedling growth of Lathyrus sativus and Pisum sativum var. abyssinicum. African Journal of Plant Science, 8(5), 225-231.

Turhan, A., Kuşçu, H., \& Şeniz, V. (2011). Effects of different salt concentrations (NaCl) on germination of some spinach cultivars. Uludă̆ Üniversitesi Ziraat Fakültesi Dergisi, 25(1).

Zehra, A., Gul, B., Ansari, R., Alatar, A., Hegazy, A., \& Khan, M. A. (2013). Interactive effect of salt, light and temperature on seed germination and recovery of a halophytic grass-Phragmites karka. Pak. J. Bot, 45(3), 725-736. 
Effect of Four Different Salts on Seed Germination and Morphological Characteristics of Oryza sativa L. cv. MR219

Zhang, D., Wang, Z., Wang, N., Gao, Y., Liu, Y., Wu, Y., Bai, Y., Zhang, Z., Lin, X., \& Dong, Y. (2014). Tissue culture-induced heritable genomic variation in rice, and their phenotypic implications. PloS one, 9(5), e96879.

Zhu, G., Kinet, J.-M., \& Lutts, S. (2001). Characterization of rice (Oryza sativa L.) F3 populations selected for salt resistance. I. Physiological behaviour during vegetative growth. Euphytica, 121(3), 251-263.

Citation: Nahid Kalhori, et al.., " Effect of Four Different Salts on Seed Germination and Morphological Characteristics of Oryza sativa L. cv. MR219", International Journal of Advanced Research in Botany, vol. 4, no. 1, p. 29-45, 2018. http://dx.doi.org/10.20431/2455-4316.0401005

Copyright: (C) 2018 Authors. This is an open-access article distributed under the terms of the Creative Commons Attribution License, which permits unrestricted use, distribution, and reproduction in any medium, provided the original author and source are credited. 